\section{International Collaborations}

\section{BRINGING TOGETHER OCCUPATIONAL AND ENVIRONMENTAL MEDICINE SPECIALISTS - DEVELOPMENT OF THE INTERNATIONAL OCCUPATIONAL MEDICINE SOCIETY COLLABORATIVE (IOMSC)}

Richard JL Heron*. Vice-President, Health and Chief Medical Officer, BP International Ltd, Middlesex, UK

\subsection{6/oemed-2018-ICOHabstracts.619}

Introduction In 2013, ACOEM and SOM convened leaders from national occupational medical societies to discuss mutual issues in global occupational and environmental medicine (OEM) and established the International Occupational Medicine Society Collaborative (IOMSC). IOMSC's mission is to improve workers' health and workplace safety on a global scale. It provides OEM societies opportunities to gain the knowledge and expertise required of OEM physicians; tools/ resources to educate their members; practices by what has been proven to work; and the ability to reach all global regions with more effective OEM care. Its active participants are delegates appointed by occupational medical organisations, world over, and currently includes 40 societies in 36 countries.

Methods IOMSC conducted a member survey (July 2015) to quantify the reach of IOMSC globally and identify common modes of OEM practice and key changes in the workplace. IOMSC plans to develop projects to address challenges identified (e.g., assist with education/training of physicians to share best practices; summarise scope of OEM practice in a position paper; develop guidebook on how to establish and promote the role of the society).

Result Survey results $(n=21)$ indicated that OEM practitioners encounter similar challenges including the growing complexity of diseases/illnesses; rapid change in workforce and population trends; and shifting legislative and economic policies that impact the profession. Scope and delivery mode of OEM services varies widely among countries, being influenced by governmental/regulatory structures.

Discussion With IOMSC, OEM societies can create a strong case to explain the value of OEM to employers, workers, the medical community, and governments. IOMSC can help increase awareness of OEM in terms of using its preventive strategies and risk assessments to prevent injury/illness and helping employers understand the value of good health in enhancing productivity and profit. IOMSC is well positioned to address professional issues and advance OEM through education, sharing best practices, and advocacy.

\section{WHAT IS THE GLOBAL IMPACT OF THE NEW (2016) OSHA SILICA DUST STANDARD?}

David F Goldsmith*. George Washington University, Washington DC, USA

\subsection{6/oemed-2018-ICOHabstracts.620}

Introduction In 2016 the U.S. Occupational Safety and Health Administration (OSHA) completed a new standard for workplace crystalline silica. We are trying to understand what this will mean outside the U.S.

Methods/current situation On March 24, 2016 OSHA issued a revised silica dust rule setting levels in construction and general industry at $50 \mathrm{ug} / \mathrm{m} 3$ for 8 hour workday- $1 / 2$ of the $100 \mathrm{ug} / \mathrm{m} 3$ previous standard. More information available https://www.federalregister.gov/documents/2016/03/25/201604800/occupational-exposure-to-respirable-crystalline-silica. OSHA is now labelling respirable silica a known human carcinogen, as it has been judged by IARC since 1996. In addition to silica being known to cause silicosis, it is now judged to be linked with auto-immune and kidney diseases. The new rule expected to save 600 lives and 900 cases of silicosis annually in U.S.

Results The World Health Organisation (WHO) is leading efforts to document the numbers of silicosis cases worldwide. Although the rates of silicosis have declined in most industrialised nations, they appear to be steady or rising in Asia, Africa, South America and the former Soviet Union. In South Africa, there is a strong effort to control silica dust because it is linked with excess silico-tuberculosis (silicoTB), especially in migrant gold miners. OSHA is likely to be asked by other global regulatory agencies to share their work, though we do not expect the new administration to be very supportive. There may be some collaboration to study nonsilicosis lung diseases, lung cancer and other cancer endpoints in countries such as South Africa, China and Chile. In the Philippines there have not been any published research, but there should be a focus on education of miners and construction workers.

Discussion The new OSHA silica rule may spur other nations to adopt the new $50 \mathrm{ug} / \mathrm{m}^{3}$ standard, to undertake novel research studies, and to offer education to alert workers to silica's health risks.

\section{FUTURE OF WORK AND OCCUPATIONAL SAFETY AND HEALTH: AN OVERSIGHT OF THE NORDIC FUTURE OF WORK AND OSH REPORT}

${ }^{1}$ Yogindra Samant, ${ }^{2}$ Magnus Falk, ${ }^{3}$ Päivi Mattila-Wiro, ${ }^{4}$ Sture Bye, ${ }^{5}$ Oscar Vargas, ${ }^{6}$ Xabier Irastorza, ${ }^{7}$ Nancy Leppink. ${ }^{1}$ Norwegian Labour Inspection Authority, Trondheim, Norway; ${ }^{2}$ Work Environment Authority, Stockholm, Sweden; ${ }^{3}$ Ministry of social affairs and health, Tampere, Finland; ${ }^{4}$ National Institute of Occupational Health, Oslo, Norway; ${ }^{5}$ European foundation for the Improvement, Dublin, Ireland; ${ }^{6}$ European Agency for Safety and Health at Work, Bilbao, Spain; International Labour Organization, Geneva, Switzerland

\subsection{6/oemed-2018-ICOHabstracts.621}

Introduction In 2016 representatives from different state organisations working with $\mathrm{OSH}$ in the Nordic countries joined up to identify challenges in work and work life today and tomorrow. The principal aim after that was to formulate ideas on how to tackle these challenges - and present recommendations to the national labour inspectorates based on this. The report is entitled Diversity of the future workforce and work tasks - challenges to OSH.

Results Pace of change within the work market in the Nordic countries is fast, it brings a high degree of complexity, and the identified challenges begs the attention of the labour inspections to prepare in advance. The report states that there is a need to look more closely on (amongst others): the changing nature of work and its location - safety 